\title{
Targeted Retroviral Gene Transfer into the Rat Biliary Tract
}

\author{
Jesus A. Cabrera, ${ }^{1}$ James M. Wilson, ${ }^{3}$ and Steven E. Raper ${ }^{2,4}$ \\ ${ }^{1}$ University of Michigan Medical School; ${ }^{2}$ Institute for Human Gene Therapy. Room 206, Wistar Institute, 36th and Spruce \\ Streets, Philadelphia, Pennsylvania 19104-4268; ${ }^{3}$ Department of Molecular and Cellular Engineering, Department of \\ Surgery, University of Pennsylvania Schoot of Medicine
}

Received 13 December 1995-Final 13 December 1995

\begin{abstract}
The ability to induce proliferation by temporary duct ligation suggested an hypothesis that retrovirus-mediated gene transfer into cells of the biliary tract could be accomplished. The time course of histologic changes, incorporation of ${ }^{3} \mathrm{H}$-thymidine and immunofuorescent staining with a monoclonal antibody to cytokeratin-19 (a marker for differentiated bile ducts) was studied in male Fischer $F 344$ rats. A recombinant Gibbon ape leukemia virus (GALV), containing a gene encoding Escherichia coli $\beta$-galactosidase was next introduced into 24 hrobstucted bile ducts. Gene transfer was maximal when virus was exposed to the obstructed duct for $12 \mathrm{hr}(\sim 0.1 \%)$. The majority of $X$-gal positive cells were in cytokeratin 19 aegatie perbiliary tissues, which had the appearance of newly forming bile whes. The dotu sugren that cells sargeted by retroviral infection of the

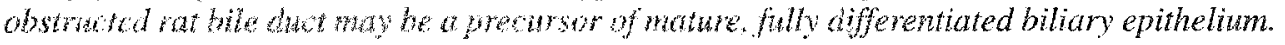

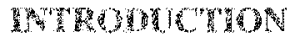

The ability to transfer foreign genetic material into the biliary tract would be useful in sudies of hepatic cell lineage as well as for the developnent of novel gene therapy strategies for the treament of biliary manfestations of carner, cystic fibusis or other genetic diseases. Eiticient gene transfer has been acompished with reconbinat alduninuses. bovever the use of curen generation adenoriruses is

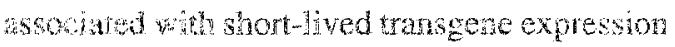
and huternation (1, 2). Retroviuses are angonater wh long-term tranggene expression mud to not strundate infammation, but successhut statezies for retrovirus mediated gene ransfer requits that the target tissue is achely prolferating $(3)$, cells such as those of the whar ract, undergo minimal proliferarion wher nomal crommentas but can be induced to prohiferate by bile duct occhsion (4-8). The ability to induce biliary ductal proliferation by duct ligation led to an hypothesis that recombinant retroviruses could be used to accomplish gene transfer in cells of the biliary tract.

A defined series of histologic changes in the bile ducts and periductular tissues have been observed. Such changes inciude dilation of existing ducts, develorment of new ductal wssues (nexcholangioles), and an increase in non-hontoryte tissue in the perpont areas (4-8). The origin of neocholangiole tissue after duct ligaton is a mater of debate, but studies of thymitine uptake clearly support the presence of ackive cellular probterition $(9,10)$.

To rest the hypothesis that retrovirusmedicted gene tanser into the billary tract might be fandinat by bile duct ligationinduced biliary epithelial proliferation. the Fischer F344 rat was subjected to varying lengths of bile duct obstuction. Changes in Her and bitiry bistorogy were siudied and the 
kinetics of thymidine incorporation were evaluated. A monoclonal antibody to cytokeratin 19, a marker for differentiated biliary epithelial cells was used in immunocytochemical studies to evaluate the state of differentiation of proliferating cells. Lastly, a recombinant Gibbon ape leukemia (GALV) retrovirus containing lac Z, a bacterial $\beta$-galactosidase gene derived from Escherichia coli, was introduced into the obstructed bile duct to examine the efficiency of gene transfer.

\section{MATERIALS AND METHODS}

Surgical Techniques. The animals used were 200-250 gram male Fischer F344 rats. Protocols conformed to the NIH Guidelines for Care and Use of Animals, and were approved by the University of Michigan IACUC. Isoflurane and supplemental oxygen were used as an anesthetic (11). After laparotomy, the common bile duct was identified as it entered into the duodenum. In studies to determine obstructioninduced morphologic changes and proliferative response, the bile duct was ligated near the duodenum for $0,6,12,24,48$ or 72 hours. Two hours prior to sacrifice, the animals were injected with ${ }^{3} \mathrm{H}$-thymidine $(1 \mathrm{mCi} / \mathrm{gram}$ body weight) into the femoral vein. Liver tissue was harvested, pieces were embedded in OCT compound (Miles Inc., Elkhart, Indiana), and quick frozen in liquid nitrogen.

Histologic Analyxis and Thymidine Autoradiography. To study the morphologic changes induced by bile duct ligation, fresh frozen sections were prepared on glass slides, fixed in $0.5 \%$ glutaldehyde for 10 minutes, and stained with hematoxylin and eosin. For autoradiographic analysis of the proliferative response in liver tissue induced by bile duct ligation, fresh frozen sections were obtained from the animals with timed bile duct ligation, fixed in $0.5 \%$ glutaldehyde for 10 minutes then processed for autoradiography. Standard autoradiographic methods were used (12). Emulsion (NTB-2), D19 developer and fixer were from Eastman
Kodak, Rochester, New York. The emulsion was exposed for 7 or 28 days before the slides were developed. Once developed, the slides were stained with hematoxylin and eosin. A proliferation index was determined by counting the cells in high powered microscopic fields in the area of at least 3 portal regions for each time point. The tissue section was arbitrarily divided into two distinct regions, the liver parenchyma (LP) and the bile duct region (BD). The percent of proliferating cells in each region was calculated by counting the number of cells that had taken up the ${ }^{3} \mathrm{H}$-thymidine into their nucleus and dividing by the total number of cells in the region.

Immunofluorescence Microscopy. To determine whether the increased peribiliary tissue was composed of differentiated biliary epithelial cells, fresh frozen sections were obtained from animals that had bile duct ligation for $0,12,24$, 48 , or 72 hours. Sections were analyzed for the presence of rat cytokeratin 19 by indirect immunofluorescence. The sections were fixed in ice cold methanol for 10 minutes and then air dried. After rehydration in PBS for $3 \mathrm{~min}$, the sections were blocked with $20 \%$ donkey serum in PBS for 30 minutes at room temperature. The sections were then incubated for 90 minutes at room temperature with a mouse monoclonal anti-rat cytokeratin 19 diluted 1:400 in $2 \%$ donkey serum (Sigma Co St. Louis, Missouri). The sections were washed three times with $2 \%$ donkey serum, incubated with a Texas Redconjugated donkey polyclonal anti-mouse antibody for 90 minutes at room temperature, and washed three times with $2 \%$ donkey serum. Cytokeratin 19 staining was visualized by fluorescent microscopy.

Retroviral Gene Transfer. To assess the optimal time of retroviral exposure and to maximize gene transfer, animals underwent bile duct ligation for 24 hours, a time point chosen for maximal ${ }^{3} \mathrm{H}$-thymidine incorporation, followed by an injection of retrovirus into the distended bile duct. A replication defective GALV retrovirus containing the $\beta$-galactosidase 
reporter gene was harvested from the packaging cell line 194-7 and supplemented with $8 \mathrm{mg}$ of Polybrene per $\mathrm{ml}$ of retrovirus (13-15). The 194-7 cell line was the highest titer clone derived from co-transfection of the plasmids MFGlacZ and pSV2neo into the GALV packaging cell line PG-13 (16, 17). The retroviral exposure was allowed to occur for $0,2,12$, or 24 hours. At the end of retroviral exposure, the bile duct ligation was released. Animals were sacrificed 7 days after the retroviral infection. Fresh frozen sections obtained from these rats were stained for $\beta$-galactosidase activity for 12 hours and then counterstained with hematoxylin and eosin. The location of the cells that stained positive for $\beta$-galactosidase activity were assigned to either liver parenchyma (LP) or the bile duct region (BD).

\section{RESULTS}

Bile Duct Proliferation as a Result of Bile Duct Ligation. Rats were subjected to bile duct ligation for $0,6,12,24,48$, or 72 hours. Two hours prior to sacrifice, the animals were injected with ${ }^{3} \mathrm{H}$-thymidine $(1 \mu \mathrm{Ci} / g r a m$ body weight, sp. act. $1 \mathrm{mCi} / \mathrm{mmol}$ ) directly into the femoral vein, an approach chosen to insure complete intravascular delivery. The liver tissue was harvested and fresh frozen sections were processed for autoradiography. A marked increase of cells incorporating ${ }^{3} \mathrm{H}$-thymidine was noted 24 hours after ligation when compared to rats subjected to sham ligation (Fig. $1 \mathrm{~A}$ and $\mathrm{C}$ ). Cells induced to proliferate after 24 hours of bile duct ligation were located in the periportal region, and included bile duct epithelial cells as well as cells of the peribiliary tissue surrounding the bile ducts. Hepatocyte parenchymal cells did not begin to enter the cell cycle until the bile duct was ligated for 48 to 72 hours. After 48 hours of bile duct ligation, cells entering the cell cycle were found both in the bile duct and in liver parenchyma. For this reason, $24 \mathrm{hr}$ after bile duct ligation was selected as the time point for use in these studies.
Morphologic changes were induced over time by bile duct ligation (Fig. 1B and D). At the end of bile duct ligation, the liver was harvested and fresh frozen sections were prepared and stained with hematoxylin and eosin. Changes in tissue morphology, as noted by distention of the bile ducts, were observed as early as 12 hours after duct ligation. After 24 hours of ligation, distention of the bile duct region, and an increase in the number of cells between the bile ducts were noted. After 48 hours, further distention and increase in the size of the bile duct region was noted. Increased numbers of cells in the bile duct region were also seen, as hematoxylin and eosin staining of the bile duct region clearly delineated this tissue as distinct from liver parenchymal cells.

To assess the proliferative response in a more quantitative manner, 3-5 portal areas from duplicate rats at each time point were selected and the cells in each high power field were counted. Cells were scored positive or negative for ${ }^{3} \mathrm{H}$-thymidine uptake based on the presence or absence of concentrated grains over cell nuclei and the percent of the cell population incorporating ${ }^{3} \mathrm{H}$-thymidine was calculated. The percent of cells in the bile duct region incorporating ${ }^{3} \mathrm{H}$-thymidine was low at 0,6 , or 12 hours, increased to a maximum at 24 hours (26.3\%) after duct ligation and decreased thereafter (Table 1). The number of cells in the liver parenchyma incorporating ${ }^{3} \mathrm{H}$-thymidine was below $1 \%$ in animals receiving bile duct ligations for 24 hours, and increased to 6.1 and $6.9 \%$ in animals that had 48 or 72 hours of duct obstruction, respectively (Table 1).

Cytokeratin 19 Staining of Bile Ducts Subjected to Duct Ligation. To assess whether increased biliary tissue noted after bile duct ligation consisted of mature biliary epithelial cells, fresh frozen sections were prepared after bile duct ligation for $0,6,12,24,48$, or 72 hours. Sections were incubated with a primary antibody that recognizes rat cytokeratin 19 , a cytoskeletal protein found in differentiated bile duct epithelial but not in liver parenchymal cells 

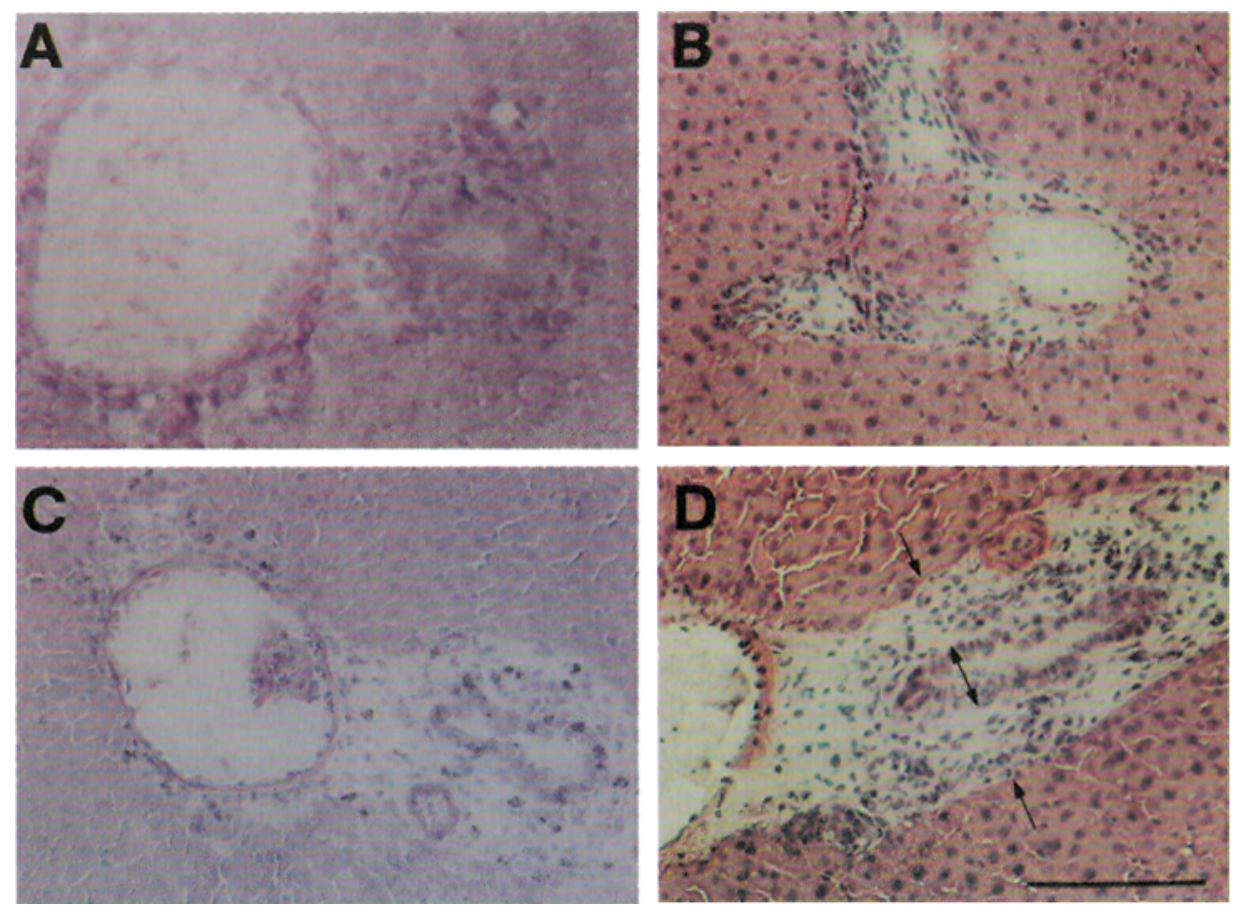

Fig. 1. Autoradiographic and histological changes accompanying progressive periods of bile duct ligation. As the length of duct obstruction increases, significant features include duct dilatation, formation of small duct-like structures (neocholangioles). and an increase in peribiliary non-parenchymal tissue. A time course study was done to determine the effect of bile duct ligation on rat liver tissue and analyzed as described in Materials and Methods. Rats underwent bile duct ligation at the level of the junction of the common bile duct and the duodenum. Two rats were sacrificed for each time point. Two hours prior to sacrifice, ${ }^{3} \mathrm{H}$-thymidine $(1 \mu \mathrm{Ci} / \mathrm{gm}$ body weight) was injected via the femoral vein. Liver was harvested and snap-frozen in OCT mounting compound. $6 \mu \mathrm{m}$ sections were cut on a cryostat, and analyzed as described in Materials and Methods. A) ${ }^{3} \mathrm{H}$-Thymidine autoradiography of rat liver subjected to sham bile duct ligation. B) Routine histology of rat liver subjected to sham bile duct ligation $(\mathrm{H} \& \mathrm{E})$. C) Thymidine autoradiography of rat liver subjected to bile duct ligation. Maximum ${ }^{3} \mathrm{H}$-thymidine incorporation occurs $24 \mathrm{hr}$ after duct ligation, with much of the incorporated thymidine found in newly formed peribiliary tissue. D) Routine histology of rat liver subjected to $24 \mathrm{hr}$ bile duct ligation H\&E stain. Note the marked increase in peribiliary tissue (Arrow's). Marker bar represents $320 \mu \mathrm{m}$ in all panels.

(6). Bile ducts in a portal region of the liver in animals with bile duct ligation immediately prior to sacrifice, were small and few in number (Fig. 2A and B). An increase in the diameter of bile ducts as well as the number of duct-like structures was present in tissue harvested from animals with bile duct ligation for 12 hours. In animals that received bile duct ligations for 24 and 48 hours, there was an increase in the size and the number of bile ducts present in the portal region of the liver tissue (Fig. $2 \mathrm{C}$ and D). Only the differentiated biliary epithelium lining identifiable ducts stained positive for expression of cytokeratin 19 , the peribiliary tissue was negative, and was comprised predominantly of structures which appeared to be newly forming cholangioles.

Optimization of Retroviral Gene Transfer. A series of experiments was designed to determine the optimal time of retroviral exposure in the biliary tract to maximize productive retrovirus-mediated gene transfer. The bile duct ligation was maintained for 24 hours prior to retroviral administration, to maximize proliferation. At this point the animal was injected with 2 $\mathrm{ml}$ of conditioned media containing the recombinant retrovirus obtained from packaging cell line 194-7. The titer of this retrovirus was $6 \times$ $10^{5}$ lac $\mathrm{Z}$ forming units per $\mathrm{ml}$ as determined on the rat fibroblast cell line Rat 1 . At the end of the 
Table 1. Quantitative Analysis of ${ }^{3} \mathrm{H}$-thymidine Incorporation into Liver Tissue After Bile Duci Obstruction"

\begin{tabular}{|c|c|c|}
\hline \multirow[b]{2}{*}{ Time } & \multicolumn{2}{|c|}{ Percent of cells with ${ }^{3} \mathrm{H}$-Thy positive nucle } \\
\hline & $\begin{array}{l}\text { Bile duct } \\
\text { region (\%) }\end{array}$ & $\begin{array}{c}\text { Liver } \\
\text { Parenchyma }(\%)\end{array}$ \\
\hline 0 & 1 & 1 \\
\hline 6 & $<1$ & 0 \\
\hline 12 & $<1$ & 0 \\
\hline 24 & 26 & $<1$ \\
\hline 48 & 24 & 6 \\
\hline 72 & 10 & 7 \\
\hline
\end{tabular}

Rass underwent bile duct ligation at the level of the junction of the common bile duct and the duodenum for increasing periods of time. Two rats were sacrificed for each time point. Two hours prior to sacrifice, ${ }^{3} \mathrm{H}$-thymidine was injected via the femoral vein. Liver was harvested and snap frozen in OCT mounting compound $6 \mu \mathrm{m}$ sections were cut on a cryostat, and analyzed as described in Materials and Methods. Qualitatively, maximum ${ }^{3} \mathrm{H}$-thymidine incorpotation occurs $24 \mathrm{hr}$ after duct ligation, with much of the incorporation found in newly formed peribiliary tissue. To determine the type of cells incorporating $3 \mathrm{H}$-thymine, enough protal tracts were photographed to allow counting of at least 1000 nuclei per rat. Cells were scored as belonging to either the liver parenchymal (LP) or bile duct region (BDL). The data are expressed as the mean percent of total nucler labeled ( $N=2$ rats each time point).

time of exposure, sutures maintaining bile duct ligation at the level of the duodenum were removed. When the retroviral exposure was 0 to 2 hours in duration, no cells were transduced. At 12 hours, maximal gene transfer was noted by cells staining positive for $\beta$-galactosidase, and this number was slightly lower in animals exposed to virus for $24 \mathrm{hr}$. Liver tissue infected with an alkaline phosphatase-containing retrovirus aid not denonstrate any cells which staned positive with the $Z$-gal reagent (data not shown,

To documer in whot compartment the retroviraly infected X-gal postive colls were located. hee different companments were abitrarily assigned: the liver parombym consisting of hepatocyces: the perbifuny conparmert. on non-parenchymal tisue surowening but rot induling the achut bibay duct

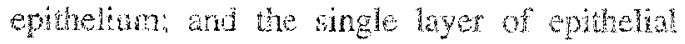
cells linng the bile ducts. Aproxinately 640 nmm $^{2}$ of stained tissue sectons were andyzed from each of three separate slides in duplicate animals, and scored in one of three categories as described above. A percentage was calculated according to the formula:

[Xgal positive cells in compartment]

[Total Xgal positive cells]

Using this formula, the peribiliary compartment comprised $76 \%$ of all $\beta$-galactosidase positive cells, mature bile duct epithelial cells comprised $13 \%$ of the total $\beta$-galactosidase positive cells, and liver parenchymal cells comprised only $11 \%$ of all $\beta$-galactosidase positive cells.

\section{DISCUSSION}

In this study, successful retrovirus-mediated gene transfer was achieved in cells of the biliary tract, but not as expected, predominantly in epithelial cells lining mature bile ducts. The primary target of retroviral gene transfer was a proliferating population of non-parenchymal cells in the bile duct regions that lacked biliary epithelial specific cytokeratin-19 markers (Fig. 2). These proliferating, yet undifferentiated cells have properties consistent with a progenitor, or stem cell population.

The existence of liver stem cells capable of generating hepatocytes, or under certain conditions, bile ducts, remains an area of controversy. Under normal conditions, the immense proliferative capacity of liver and the turnover of hepatocytes and bile duct epithelial cells is adiugate to mantain cell mass, thus obviacing the need for a progenitor cell population. Evidence of a stem cell comparment in nomal and abnomal adult ther tissue has, however, been sited by several diferent inbomores 9 , 10, 18. 19). Wodes of the extstenos of an active

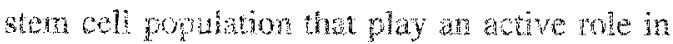

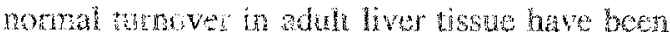
proposed. Zaher? and colleagues have suggested a model of cell "rreaning" during

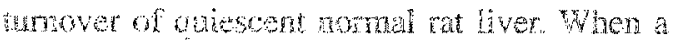
populaton we cels in the guiescen liver were labeled with mined thymidne, posinge cells 

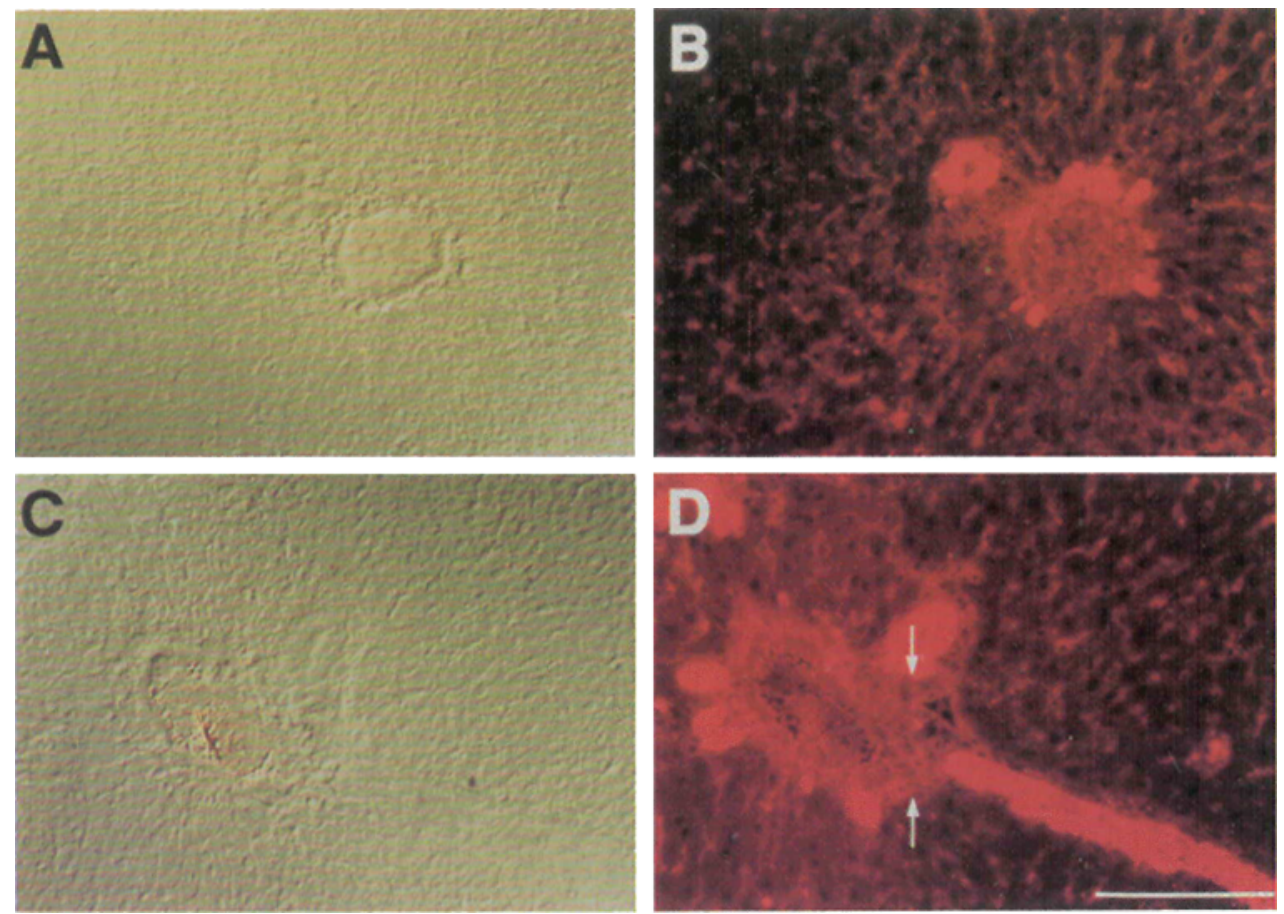

Fig. 2. Cytokeratin-19 expression induced by bile duct ligation. A) Nomarski photomicrograph of liver tissue from a rat subjected to sham bile duct ligation. B) Fluorescent photomicrograph of liver tissue from a rat subjected to sham bile duct ligation showing ducts staining for Texas red conjugated anti-rat cytokeratin-19. Note that only well formed ducts stain positive for cylokeratin- 19. C) Nomarski photomicrograph of liver tissue from a rat subjected to 24 hr bile duct ligation. D) Fluorescent photomicrograph of liver tissue from a rat subjected to $24 \mathrm{hr}$ bile duct ligation showing ducts staining for Texas red conjugated anti-rat cytokeratin-19. Note the increase of non-parenchymal peribiliary tissue which does not stain with the antibody (Arrows) Marker represents $640 \mu \mathrm{m}$.

resided within 300 microns from the rim of the periportal tract $(9,10)$. With time, the labeled cells appeared to migrate towards the central vein. The data suggest that there exists a population of cells in the periportal region that replicates and can give rise to mature hepatocytes. Reid has extended the "streaming hypothesis" of Zajicek by describing a lineage position-dependen 1 phenotype with respect to morphology, gene expression, ploidy, and growth potential, in vivo and in vitro (18).

By transducing hepatocytes with retroviruses expressing a muclear targeted form of $\beta$-galactosidase, no change in the distribution of labeled hepatocytes in the lobule was noted. This provides evidence against the "streaming hypothesis" and for clonal proliferation of mature hepatocytes (20). The studies described here are analogous to similar attempts to mark hepatocytes by retrovirus-mediated gene transfer. Gene transfer was accomplished by stimulating proliferation by ligation of the rat common bile duct. The primary target of retroviral gene transfer was a proliferating population of non-parenchymal cells in the bile duct regions that lacked biliary epithelial specific cytokeratin-19 markers (Fig. 2). Morphologic changes were apparent as early as 12 hours after bile duct ligation and a proliferative response, as measured by tritiated thymidine uptake was observed after duct ligation of 24 hours. Cells that incorporated ${ }^{3} \mathrm{H}$-thymidine after bile duct ligation of 24 hours included bile duct epithelial cells and the neocholangiole cells in the peribiliary region but did not include hepatocytes in the liver parenchyma. Proliferation of 
the typical bile ducts present in the portal tracts, as determined by indirect immunofluorescence of the expression of rat cytokeratin 19, also increased. Neocholangiole cells in the periportal region also increased in number, however, they did not appear to stain positive for cytokeratin 19 expression. When the biliary tract was exposed to a recombinant GALV retrovirus containing the $\beta$-galactosidase reporter gene after bile duct ligation for 24 hours, gene transduction was achieved. The cells that were retrovirally infected were predominately in the peribiliary region $(76 \%)$ and to a lesser extent in hepatocytes in the parenchyma $(11 \%)$ or the mature bile duct epithelial cells which line well formed bile ducts (13\%).

The primary target of retroviral gene transfer was a proliferating population of non-parenchymal cells in the periportal areas that lacked biliary epithelial specific cytokeratin-19 markers (Fig. 3). These proliferating, yet undifferentiated cells have the properties commonly ascribed to a progenitor, or stem cell, population. The data presented in this report suggest that a population of undifferentiated cells within the liver is induced to proliferate by bile duct ligation. These cells can be marked by retroviral infection and will allow study of cell lineage relationships and developmental potential (21). The proposed location of the stem cell compartment has been the periportal region and experimental model described here has been developed to induce proliferation in this region. Although the anatomic location of the normal cellular counterparts to stem cells is unclear, various theories suggest that they are the terminal bile ductule cells or distinct primitive periductual stem cells. In massive or submassive hepatic necrosis, a proliferation of ductular structures also referred to as pseudoducts, neocholangioles, or ductular or biliary hepatocytes is also observed (7). These ductules are immunoreactive for bile duct specific markers, cytokeratins 19 and carcinoembryonic antigen, but also stain positive for the hepatocyte specific marker $\alpha$-1-antitrypsin (22-24). The immunofluorescent studies reported here support the model that proliferation of neocholangiole structures can demonstrate features of both differentiated hepatocytes and bile duct epithelial cells.

The proliferation of intrahepatic bile duct like structures can be induced by the ligation of the common bile duct in experimental models. Two forms of bile duct proliferation, typical and atypical, have been defined (6). Typical biliary proliferation refers to an increased number of ducts that have well-defined lumens and are confined to the portal tract. Atypical bile duct proliferation describes an increase in the number of abnormal ductular structures that do not contain well defined lumens in the periportal region. Available evidence suggests that hepatotoxic or carcinogenic agents are necessary to expand a population of stemlike cells, as bile duct ligation will not induce such a population of cells to expand. Nonetheless, gene transfer has been documented in a population of undifferentiated cells, as defined by lack of staining with cytokeratin-19. This will allow the study of developmental potential.

Another potential application of the ability to transduce proliferating cells in the biliary tract is that of transferring therapeutic genes for potential gene therapy applications. High titer recombinant adenoviruses have been used to document gene transfer into cells of the biliary tract, but adenovirus-mediated gene transfer is transient under most circumstances, and is associated with host tissue injury $(25,26)$. Retrovirus-mediated gene transfer into liver parenchymal cells has also been achieved at levels similar to those reported here for the biliary tract, but such gene transfer requires total hepatic vascular exclusion and $70 \%$ hepatectomy to stimulate a proliferative response (27). To be practical for purposes of gene therapy, higher titers of retrovirus and infection of a higher proportion of target cells will be required.

In conclusion, this study has demonstrated that cells in the biliary tract can be induced to proliferate by bile duct ligation. Proliferating cells can be transduced by retroviruses, includ- 

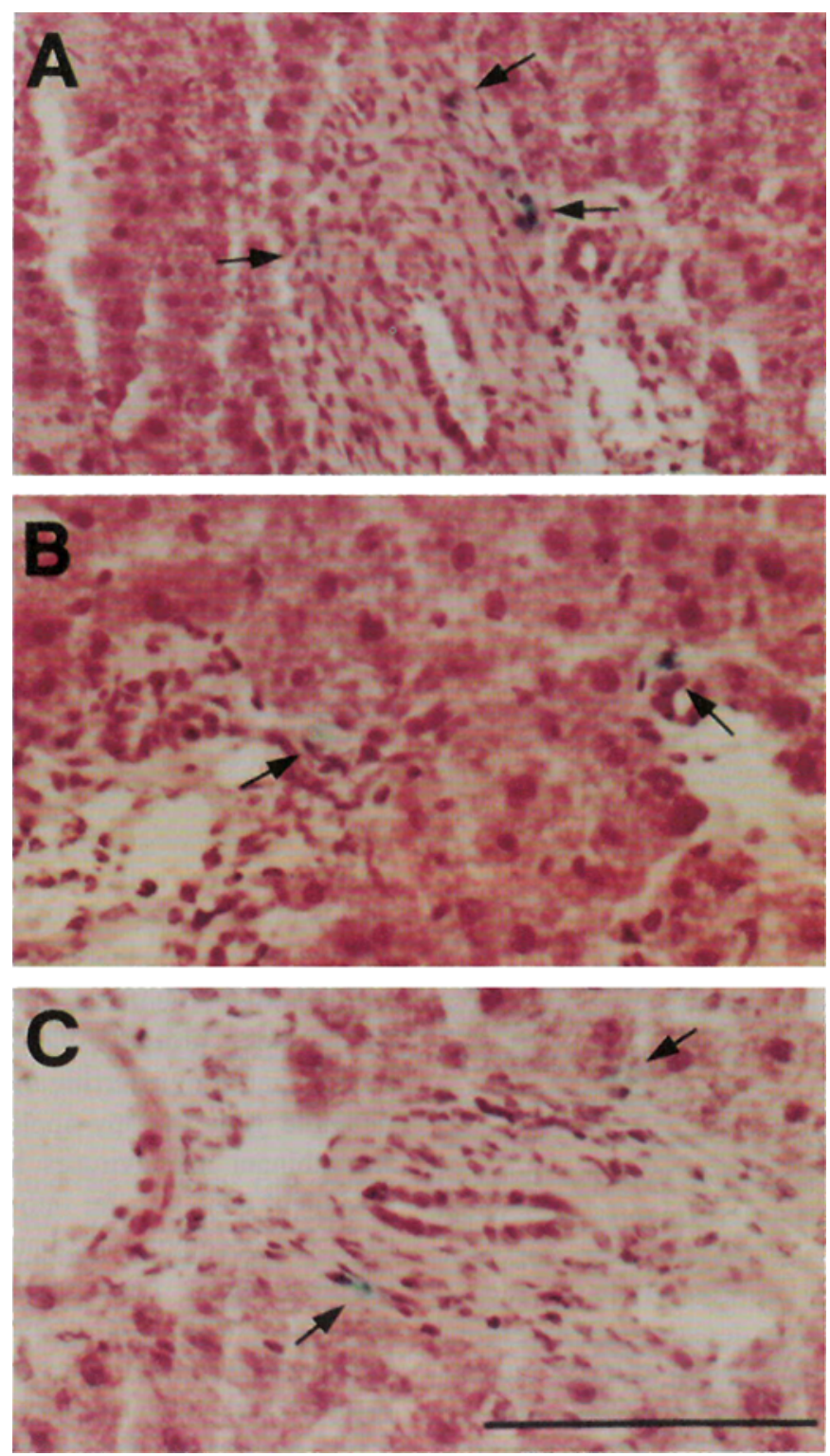

Fig. 3. Retrovirus-mediated gene transfer into the biliary tract after bile duct ligation. After 12 hr. duct ligation was released and seven days later liver was harvested for X-gal histochemical staining. A. B, C. Representative examples of positive cells in periportal tracts. Light hematoxylin counter stain, marker bar $=160 \mu \mathrm{m}$.

ing undifferentiated duct-like peribiliary tissue which does not stain positive for cytokeratin 19 , a marker for differentiated biliary epithelium, as well as mature bile duct epithelial cells. Such an approach may allow gene delivery to a population of cells that may give rise to bile duct epithelial cells or hepatocytes, and has important implications as a possible mode of stable gene transfer in therapy for treatment of liver or biliary disease. The ability to mark this population of cells will provide more information as to the developmental potential and lineage of 
these ligation-induced proliferating peribiliary cells.

\section{ACKNOWLEDGEMENTS}

Funding for this work was provided by the NIDDK of the NIH (JMW, SER). JMW is a founder of and holder of equity in GENOVO, Inc.

\section{LITERATURE CITED}

1. Yang, Y., Raper, S.E., Cohn, J.A., Engelhardt, J.F., and Wilson, J.M. (1993). Proc. Nat. Acad. Sci. U.S.A. 90:4601-4605.

2. Yang, Y., Ertl, H.C.J., and Wilson, J.M. (1994). Immunity 1:433-442.

3. Miller. D.G., Adam, M.A.. and Miller. A.D. (1990). Mol. Cell. Biol. 10:4239-4242.

4. Gall. J.A.M., and Bhathal, P.S. (1990). Liver 10:106115.

5. Gall, J.A.M., and Bhathal, P.S. (1990). Liver 10:116125.

6. Nakanuma, Y., and Ohta, G. (1986). Liver 6:205-211.

7. Phillips, M.J., and Poucell, S. (1981). Human Pathology 12:1060-1084.

8. Slott, P.A., Liul, M.H., and Tavoloni, N. (1990). Gastroenterology 99:466-477.

9. Arber. N.. Zajicek, G., and Ariel, I. (1988). Liver 8:80-87.

10. Zajicek. G., Ariel, I., and Arber, N. (1988). Liver 8:213-218.

11. Raper, S.E., Barker, M.E., Burwen, S.J., and Jones, A.L. (1987), Anat. Record. 218:116-122.
12. Stein, G.H., and Yanishevsky, R. (1979). Methods of Enzymolog!: Vol. LVIII., Academic Press, Inc., pp. 279-292.

13. Danos, O., and Mulligan, R.C. (1988). Proc. Nat. Acad. Sci. U.S.A. 85:6460-6464.

14. Gilboa, E. (1992). Bioessars 5:252-257.

15. Miller, A.D. (1992). Curr. Topics. Micro. Immunol. 158: $1-24$.

16. Dranoff, G., Jaffee, E., Lazenby, A., Golumbek, P., Levitsky, H., Brose, K., Jackson, V., Hamada, H., Pardoll, D., and Mulligan, R.C. (1993). Proc. Nat. Acad. Sci. U.S.A. 90:3539-3543.

17. Miller, A.D., Garcia, J.V., von Suhr, N., Lynch, C.M., Wilson, C., Eiden, M.V. (1991). J. Virol. 65:22202224 .

18. Sell, S. (1990). Cancer Res. 50:381 1-3815.

19. Sigal, S.H., Brill, S., Fiorino, A.S., and Reid, L.M. (1992). Am. J. Physiol. 263:G139-G148.

20. Bralet, M.P., Branchereau, S., Brechot, C., Ferry, N. (1994). Am. J. Path. 144:896-905.

21. Price, J. (1987). Development 101:409-419.

22. Evarts, R.P., Nagy, P., Marsden, E., and Thorgeirsson, S.S. (1987). Carcinogenesis 8:1737-1740.

23. Moll, R., Franke. W.W., and Schiller, D.L. (1982). Cell 31:11-24.

24. Germain, L., Blouin, M.J., and Marceau. N. (1988). Cancer Research 48:4909-4918.

25. Yang, Y., Nunes, F.A., Berencsi, K., Furth, E.E., Gonczol. E., and Wilson, J.M. (1994). Proc. Nat. Acad. Sci. U.S.A. 91:4407-4411.

26. Kozarsky, K., McKinley, D., Austin, L.L., Raper, S.E., Stratford-Perricaudet, L., and Wilson, J.M. (1994). J. Biol. Chem. 269: 13695-13702.

27. Ferry, N., DuPlessis, O., Houssin, D., Danos, O., Heard, J-M. (1991). Proc. Nat. Acad. Sci. U.S.A. 88:8377-8.381. 